\title{
PKM Validator Desain Rumah Terapung Suku Anak Dalam karya Siswa
}

\section{MAN Insan Cendekia Jambi}

Muhammar Khamdevi

Program Studi Arsitektur, Universitas Matana

\section{Abstrak}

Permukiman Suku Anak Dalam di Muara Medak - Jambi sering mengalami bencana banjir belakangan tiap musim penghujan. Hal ini banyaknya bukit yang berubah dari hutan menjadi perkebunan sawit yang tidak mampu menyerap air. Sehingga di musim hujan, kawasan ini yang merupakan rawa dangkal sering mendapat limpasan air dari bukit yang menyebabkan banjir. Siswa MAN Insan Cendikia mencoba mencari solusi desain rumah bagi warga Suku Anak Dalam di Muara Medak melalui penelitian R \& D dengan topik: "Mahaban" Alternatif Rumah Apung dalam Menangani Banjir dan Melangun bagi Suku Anak Dalam di Desa Muaro Medak Jambi. Hasil penelitian ini lalu diikutsertakan pada kompetisi Karya Tulis Ilmiah Remaja (LKIR) yang diselenggarakan oleh Badan Penelitian dan Pengembangan Daerah (Balitbangda) Jambi. Untuk memvalidasi desain tersebut, penulis membantu memberikan pendampingan dan konsultasi mengenai desain mereka. Penelitian ini menggunakan mix-method. Setelah divalidasi, desain perlu direvisi. Lalu hasilnya dibuatka prototipe dan diujicobakan. Hasilnya, desain ini memenangkan penghargaan Jurnal Terbaik II dan Juara Harapan II pada presentasi karya.

Kata Kunci: rumah terapung, pengabdian kepada masyarakat, suku anak dalam, perancangan arsitektur

\section{Abstract}

The settlement of the Anak Dalam tribe in Muara Medak - Jambi often experiences flood disasters later in each rainy season. This is the number of hills that have changed from forests to become oil palm plantations which are unable to absorb water. So that in the rainy season, this area which is a shallow swamp often gets runoff from the hills which causes flooding. MAN Insan Cendikia students try to find a home design solution for residents of the Anak Dalam Tribe at Muara Medak through $\mathrm{R}$ \& D research with the topic: "Mahaban" Alternative Floating Houses in Handling Floods and Building for Tribal Children in the Village of Muaro Medak Jambi. The results of this study were then included in the Youth Scientific Writing competition (LKIR) organized by the Regional Research and Development Agency (Balitbangda) Jambi. To validate the design, the authors help provide assistance and consultation regarding their designs. This research uses a mix-method. After validation, the design needs to be revised. Then the results were made into a prototype and tested. As a result, this design won the Best Journal Award II and the Second Champion Award at the presentation of the work.

Keywords: floating house, community service, suku anak dalam, architectural design

\section{Pendahuluan}

Suku Anak Dalam atau Orang Rimba adalah salah satu suku di Pulau Sumatera, tepatnya di Provinsi Jambi dan Provinsi Sumatera Selatan. Mereka hidup di pedalaman hutan dengan memanfaaatkan hutan untuk melangsungkan kehidupannya. Suku Anak Dalam hidup dengan cara berburu dan meramu, walaupun 
PKM Validator Desain Rumah Terapung Suku Anak Dalam oleh MAN Insan Cendekia Jambi

sekarang banyak yang telah memiliki lahan karet dan pertanian. Selain itu mereka cenderung seminomaden, berpindah dari satu tempat ke tempat lainnya yang di sebut melangun ketika ada kerabat atau warga yang meninggal, menghindari musuh, dan membuka ladang baru. Suku Anak Dalam tinggal di pondok-pondok panggung kecil yang disebut sesudungon dan yang besar disebut rumah godong. Bangunannya terbuat dari kayu hutan, berdinding kulit kayu, dan beratap daun serdang benal. Suku Anak Dalam juga memiliki kemiripan bahasa dan adat dengan suku Minangkabau, seperti sistem kekeluargaan matrilineal (Saleh, 2014; Sinaga et. al., 2015, Muslim, 2015; Muchlis, 2016; dan Kasiono, 2018).

Di Provinsi Jambi, Suku Anak Dalam berada di tiga wilayah, seperti: yaitu Suku Anak Dalam yang berada di Taman Nasional Bukit 31 sebelah utara Provinsi Jambi, Taman Nasional Bukit 12, dan wilayah perbatasan antara Provinsi Jambi dan Provinsi Sumatera Selatan (Muaro Jambi-Muara Medak). Di Muara Medak, Suku Anak Dalam bermukim di daerah rawa-rawa, tanah gambut, dan pesisir sungai. Mereka bergantung pada lingkungan perairan daripada daratan.

Berdasarkan wawancara, wilayah mereka akhir-akhir ini sering mengalami kebanjiran tiap musim penghujan. Biasanya mereka hanya berdiam diri di rumah sampai banjir surut. Akibatnya kelangsungan hidup mereka menjadi terganggu.

Oleh karena itu siswa MAN Insan Cendikia Jambi mencoba melakukan penelitan dan mengembangkan sebuah produk yang dapat membantu Suku Anak Dalam. Produk desain yang dihasilkan berjudu: "Mahaban" Alternatif Rumah Apung dalam Menangani Banjir dan Melangun bagi Suku Anak Dalam di Desa Muaro Medak Jambi. Dalam hal ini, peneliti bertindak sebagai validator desain yang dibuat tersebut. Desain ini diikutsertakan kompetisi Karya Tulis IImiah Remaja (LKIR) yang diselenggarakan oleh Badan Penelitian dan Pengembangan Daerah (Balitbangda) Jambi.

Sebenarnya konsep rumah terapung bukanlah hal baru di Indonesia. Terutama hal ini dapat dilihat pada Rumah Panggung suku Bajo dan Rumah Lanting di Kalimantan (Khamdevi, 2014). Maka diharapkan mereka bercermin dari kearifan lokal Indonesia yang menjadi dasar dalam merancang rumah terapung untuk Suku Anak Dalam di Muara Medak. Bagaimanakah validasi rumah terpaung yang dirancang oleh siswa MAN Insan Cendikia?

\section{Metode Penelitian}

Penelitian ini dilakukan dengan menggunakan metode penelitian mix-method. Metode Penelitian ini berbentuk validasi desain dengan form penilaian berbentuk checklist. 3. Skala angka terdiri dari 5 angka, dengan penjelasan sebagai berikut:

1: Tidak baik

2: Kurang baik

3: Baik

4: Cukup baik

5: Sangat baik

Hal-hal yang divalidasikan termasuk:

1. Pola Ruang (Denah)

2. Material Bangunan.

Selain diberi nilai, penulis juga memberikan komentar dan rekomendasi. Setelah desain divalidasi, maka desain direvisi, dibuatkan prototipenya, dan diujicobakan. 


\section{Hasil dan Pembahasan}

\section{Validasi Desain}

\section{Pola Ruang (Denah)}

Desain Mahaban memiliki teras di bagian depan rumah. Hal ini dikarenakan Suku Anak Dalam memiliki kebiasaan bersantai pada waktu luang biasanya pada sore hari. Kamar tidur anak perempuan dibuatkan khusus karena mereka masih tinggal bersama orang tua. Berbeda dengan remaja lelaki yang belum menikah, mereka biasanya tidur bersama di balai desa. Lokasi kamar tidur anak perempuan ditempatkan di bagian belakang. Sedangkan kamar tidur orang tua di bagian depan, lihat Gambar 1.

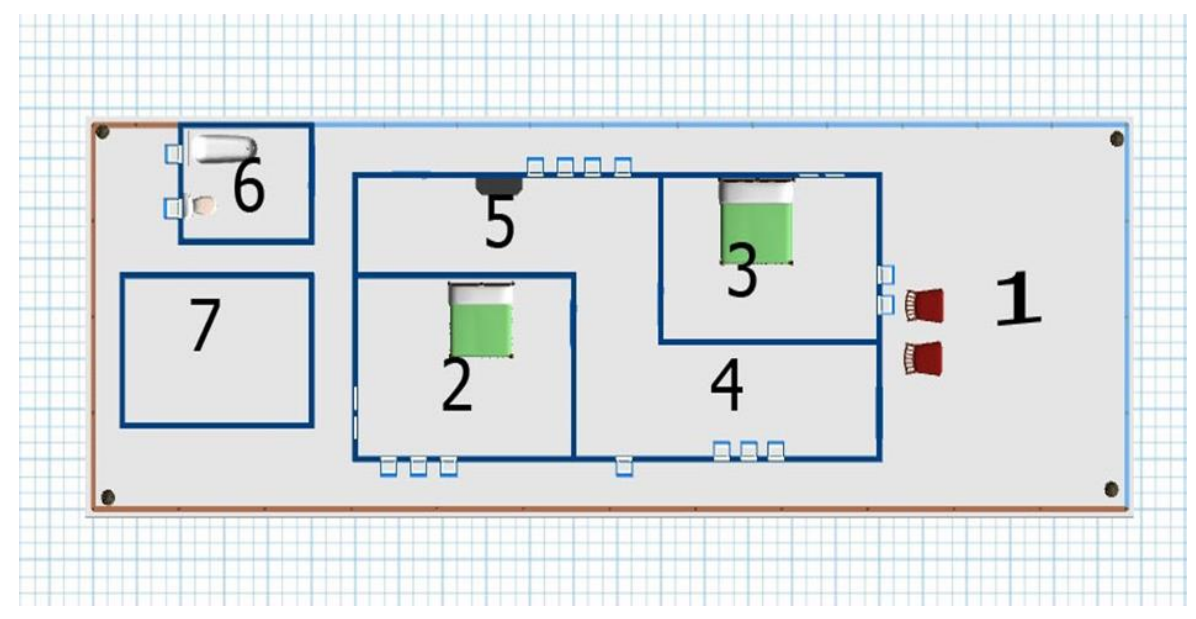

Gambar 1. Taman dan Area Hijau Kawasan

Pada denah ruang tamu dan keluarga digabungkan. Hal ini dikarenakan Suku Anak Dalam terbiasa berkumpul bersama keluarga dan menerima tamu tamu. Dapur diletakkan berdekatan dengan ruang keluarga untuk memudahkan aktifitas dari ruang keluarga menuju ke dapur atau sebaliknya. Sedangkan kamar mandi diletakkan di luar bagian belakang rumah, dikarenakan untuk memberikan kenyamanan kepada penghuni rumah dan mempertimbangkan keseimbangan rumah apung diatas permukaan sungai. Selain itu, siswa juga membuat desain keramba ikan di belakang rumah. Hal ini berfungsi sebagai tempat penyimpanan hasil tangkapan ikan.

Dalam penilaian penulis, pola ruang desain rumah terapung ini tidak disesuaikan dengan pola ruang tradisional Suku Anak Dalam. Disarankan revisi desain mengikuti prinsip-prinsip pola ruang yang sudah menjadi tradisi dan kebiasaan mereka. Dari pengalaman penulis pada saat berkunjung di wilayah Air Hitam, di dalam rumah terdapat ruang terbuka di depan dan ruang tidur anak perempuan dan orang tua di belakang. Bentuk denah cenderung persegi memanjang, lihat Tbel 1.

Tabel 1. Penilaian Pola Ruang

\begin{tabular}{|l|l|c|}
\hline No. & \multicolumn{1}{|c|}{ Ruang } & Nllai \\
\hline 1. & Teras & 4 \\
\hline 2. & Kamar Tidur Anak Perempuan & 3 \\
\hline 3. & Kamar Tidur Orang Tua & 3 \\
\hline 4. & Ruang Tamu dan Kelarga & 3 \\
\hline 5. & Dapur & 4 \\
\hline 6. & Kamar Mandi & 4 \\
\hline
\end{tabular}


PKM Validator Desain Rumah Terapung Suku Anak Dalam oleh MAN Insan Cendekia Jambi

\begin{tabular}{|l|l|c|}
\hline 7. & Keramba Ikan & 4 \\
\hline
\end{tabular}

\section{Material Bangunan}

Tambatan juga digunakan agar rumah apung dapat menetap di suatu tempat, tidak terbawa arus sungai. Tambatan ini terdapat 8 titik yang mengelilingi pondasi rumah apung. Pondasi apung berbahan dasar kubus apung HDPE. Material ini dipilih, karena kubus apung HDPE memiliki ketahanan yang kuat dan bisa tahan hingga 15 tahun, serta ramah lingkungan.

Penutup atap bangunan menggunakan daun rumbia untuk mempertahankan kesan tradisional dan memberikan efek sejuk didalam rumah. Daun rumbia juga berperan sebagai penangkal panas. Penutup atap juga dikombinasikan dengan seng, supaya atap kuat untuk menutupi kelemahan dari atap rumbia. Seng menjadi atap utama yang dilapisi oleh atap rumbia. Lantai, tiang dan dinding rumah apung berbahan dasar kayu. Kayu bersifat ringan dan kuat dan memberikan efek sejuk pada lantai dan dinding rumah. Jenis kayu sengon digunakan untuk dinding rumah karena kayu tersebut dinilai paling ekonomis dan mudah didapat, lihat Gambar 2.

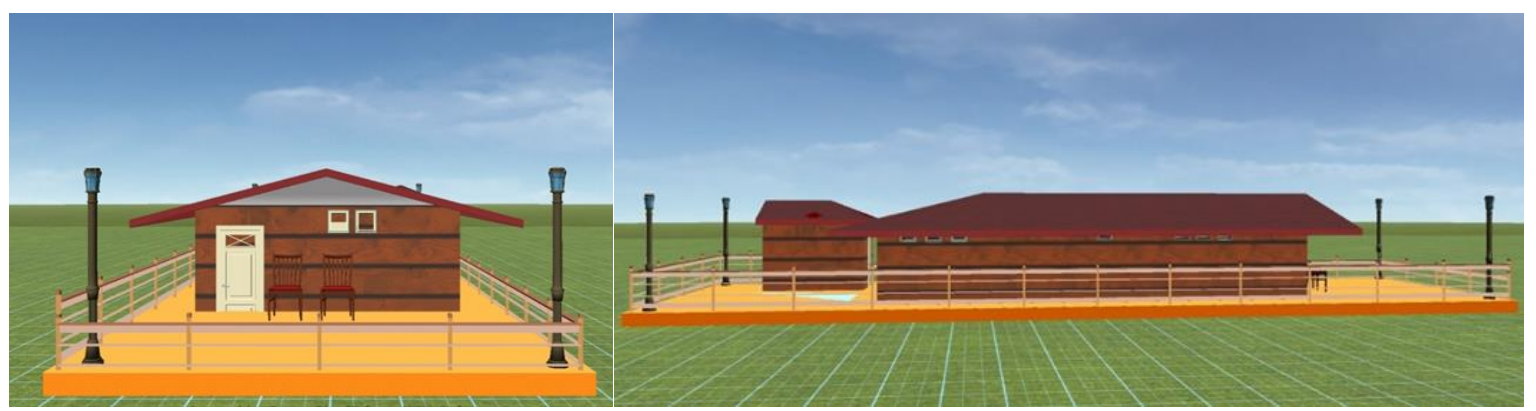

Gambar 2. Tampak Depan dan Tampak Samping Kiri

Menurut penilaian penulis, pemilihan seng sebagai penutup atap utama adalah kurang tepat. Karena seng justru merupakan bahan penghantar panas (kalor) yang baik. Sehingga ruangan di dalamnya akan semakin panas. Selain itu atap seng cenderung bising pada saat hujan. Sebenarnya penggunaan atap rumbia bisa efektif, jika proses pemasangannya benar dan bertumpuk beberapa lapisan hingga menjadi tebal, sehingga kebocoran akibat air hujan bias dihindari. Jika tidak ada seseorang ahli bangunan yang cakap, maka daripada seng akan lebih baik menggunaka atap baja ringan yang murah dengan lapisan anti panas dan kedap suara, contohnya merk "Go Green", lihat Tabel 2.

Tabel 2. Material Bangunan

\begin{tabular}{|l|l|c|}
\hline No. & \multicolumn{1}{|c|}{ Ruang } & NIlai \\
\hline 1. & Tambatan & 5 \\
\hline 2. & Atap Rumbia & 5 \\
\hline 3. & Atap Seng & 1 \\
\hline 4. & Kayu & 5 \\
\hline 5. & Kubus HDPE & 4 \\
\hline
\end{tabular}

\section{Revisi Desain}


Siswa MAN Insan Cendikia Jambi membuat revisi desain dengan melihat rekomendasi dari validator. Revisi ini terlihat dari pembuatan prototipe dengan skla 1:25. Prototipe ini pun selanjutnya diujicobakan, lohat Gambar 3.

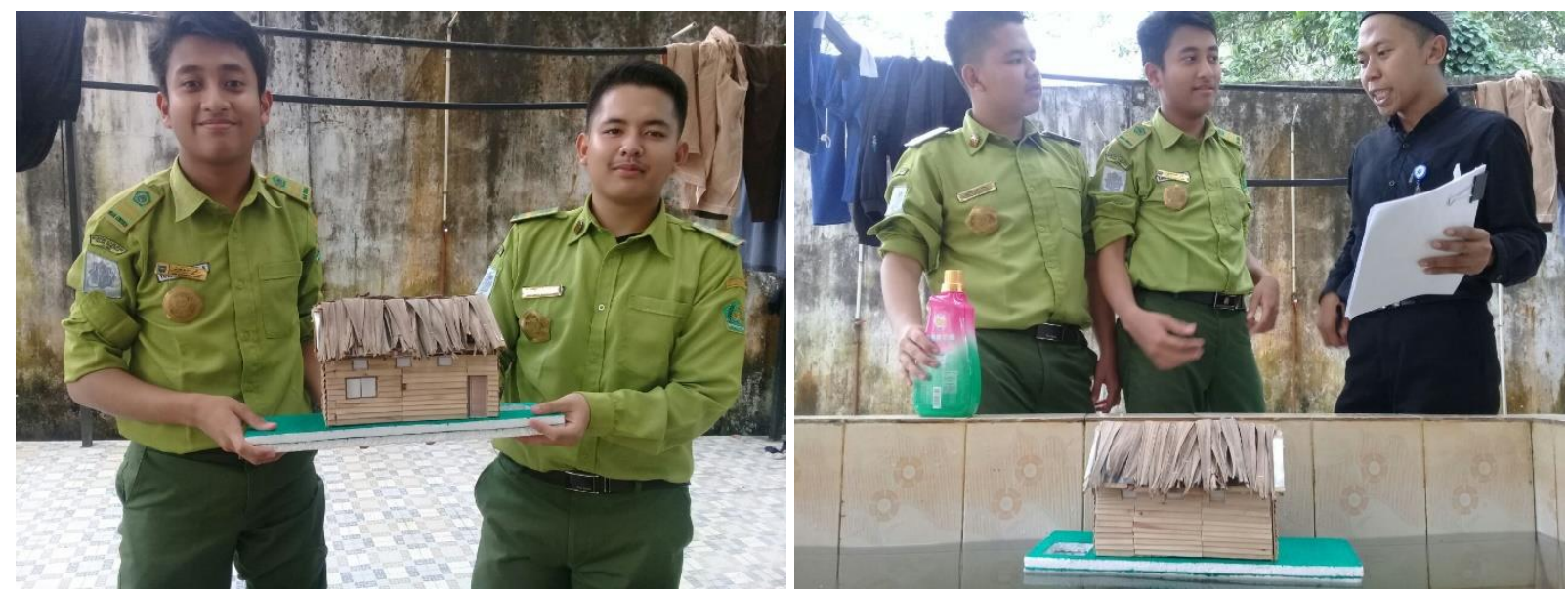

Gambar 3. Prototipe dan Uji Coba

Desain ini lalu diikutsertakan pada kompetisi Karya Tulis Ilmiah Remaja (LKIR) yang diselenggarakan oleh Badan Penelitian dan Pengembangan Daerah (Balitbangda) Jambi pada jenis kategori penelitian Research and Development (R \& D). Desain ini mendapatkan penghargaan Jurnal Terbaik II dan Juara Harapan II pada presentasi karya atas nama Rafly Aulya Rizky Nasution dan Muhammad Ainul Falah Aditya Maturidi siswa kelas XII.

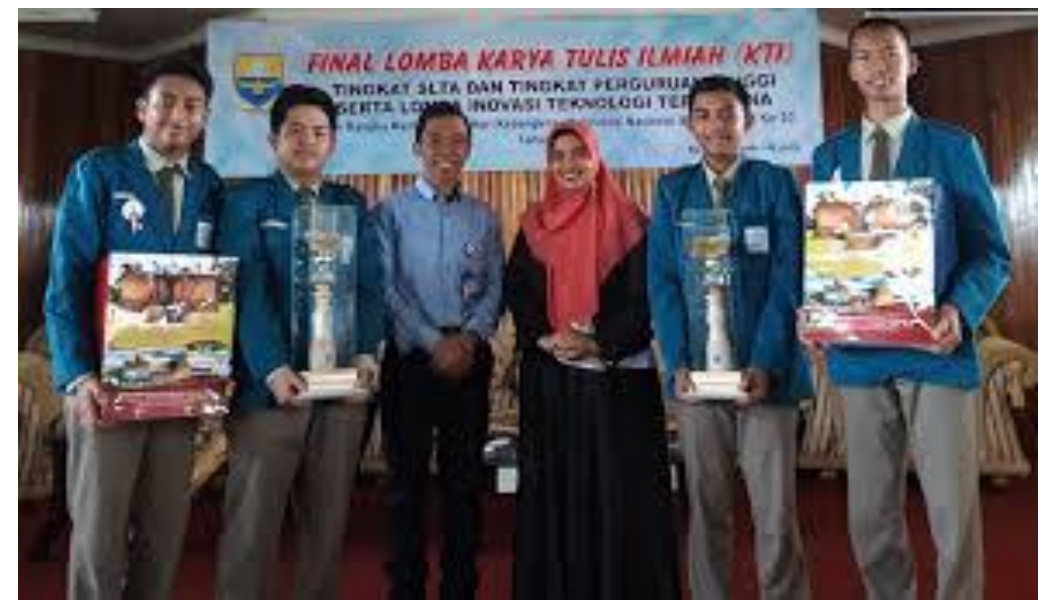

Gambar 4. Kompetisi LKIR Balitbangda Jambi

\section{Kesimpulan}

Dari hasil pembahasan, dapat disimpulkan bahwa desain Mahaban" Alternatif Rumah Apung dalam Menangani Banjir dan Melangun bagi Suku Anak Dalam di Desa Muaro Medak Jambi cukup baik namun perlu ada beberapa revisi, terutama masalah pola ruang dan pemilihan atap seng. Perancangan bangunan yang well design dalam keilmuan arsitektur adalah yang mengedepankan konteks, yaitu: Konteks Iklim dan Lingkungan dan Konteks Budaya. Pemilihan material modern dan pola ruang modern yang notabene adalah dari barat tidak melulu baik diterapkan pada konteks yang berbeda. Selain itu desain jangan sampai melunturkan atau memunahkan budaya dan tradisi lokal. 


\section{Daftar Pustaka}

Kasiono (2018). Potensi Usaha dan Pendidikan Kecakapan Hidup Berbasis Budaya (Mata Pencaharian) 'Suku Anak Dalam'. Jurnal Ilmiah Dikdaya. p.74-91

Khamdevi, M. (2014). Floating City: A Locality Based Solution Beside Land Reclamation For Future Giant Sea Wall Development Area in Jakarta Bay. Proceeding in ARCHEVENT. Surakarta: Universitas Sebelas Maret Surakarta.

Muchlis et.al. (2016). Sejarah Marginalisasi Orang Rimba Bukit Dua Belas Di Era Orde Baru. Paramita Vo. 26 No. 2 , p. 217-229.

Muslim (2015). Analisa Perkembangan Perubahan Budaya Masyarakat Kota Jambi dan Pengembangan Pola Perekonomian Masyarakat Berbasis Ekonomi Kreatif. Prosiding Seminar Nasional 9 Mei 2015. p.789-796.

Saleh, S. (2014). Agama, Kepercayaan, dan Kelestarian Lingkungan, Studi Terhadap Gaya Hidup Orang Rimba Menjaga Lingkungan Di Taman Nasional Bukit Dua Belas (TNBD) - Jambi. Kawistara Vol. 4 No. 3, p. 225-330

Sinaga dan Rustaman (2015). Nilai-Nilai Kearifan Lokal Suku Anak Dalam Provinsi Jambi terhadap Perladangan di Hutan Taman Nasional Bukit Duabelas sebagai Sumber Belajar Biologi . Seminar Nasional XII Pendidikan Biologi FKIP UNS. p. 761-766. 